\title{
Profil Darah dan Penambahan Bobot Badan Kambing Peranakan Ettawah Setelah Pemberian Vaksin Iradiasi Streptococcus agalactiae
}

\author{
(Blood Profile and Body Weight Gain of Ettawah Crossbreed Goat After Vaccinating \\ by Irradiated Streptococcus agalactiae)
}

\author{
Trinugraha AC, Handayani T, Priyoatmojo D, Tuasikal BJ \\ Pusat Aplikasi Isotop dan Radiasi, Jl. Lebak Bulus Raya No. 49, Jakarta 12070 \\ afi_candra@batan.go.id
}

\begin{abstract}
Ettawah Crossbreed (PE) goat was domesticated to fulfill human need on meat and milk. As a dairy milk producer PE goat is susceptible to subclinical mastitis. The main cause of subclinical mastitis in Indonesia is Streptococcus agalactiae. The objective of this research was to identify blood profile of PE goat which get the irradiated vaccine $S$. agalactiae to prevent subclinical mastitis caused by $S$. agalactiae. This research used pregnant healthy goats that do not produce milk. The goats were vaccinated with interval of two weeks. The vaccine volume used was $2 \mathrm{ml}$ and contain $10^{8} \mathrm{cfu} / \mathrm{ml} \mathrm{S}$. agalactiae. This study showed that irradiated vaccine of S. agalactiae does not cause anemia in goats either during pregnancy or after birth. Furthermore the irradiated vaccine does not affect the daily body weight gain of goat and its safe for hematologic system.
\end{abstract}

Key Words: Ettawah Crossbreed Goat, Streptococcus agalactiae, Irradiated Vaccine

\begin{abstract}
ABSTRAK
Kambing Peranakan Ettawah (PE) merupakan kambing yang dipelihara untuk memenuhi kebutuhan susu dan daging. Sebagai ternak penghasil susu, kambing PE juga rentan terhadap mastitis subklinis. Penyebab utama kejadian mastitis subklinis adalah bakteri Streptococcus agalactiae. Tujuan penelitian ini adalah mengetahui profil darah kambing PE dengan pemberiaan vaksin iradiasi $S$. agalactiae. Kambing yang digunakan adalah kambing sehat yang sedang bunting yang memasuki periode kering kandang dan divaksin dengan interval dua minggu. Volume vaksin yang digunakan adalah $2 \mathrm{ml}$ yang mengandung $10^{8} \mathrm{cfu} / \mathrm{ml} S$. agalactiae. Hasil penelitian menunjukkan bahwa vaksin iradiasi $S$. agalactiae tidak menyebabkan anemia pada kambing PE baik selama kebuntingan maupun setelah melahirkan. Selain itu pemberian vaksin iradiasi juga tidak mempengaruhi penambahan bobot badan harian kambing PE. Hasil ini mengindikasikan bahwa pemberian vaksin iradiasi S. agalactiae tidak mempengaruhi sistem hematologi kambing.
\end{abstract}

Kata Kunci: Kambing Peranakan Ettawah (PE), Streptococcus agalactiae, Vaksin Iradiasi

\section{PENDAHULUAN}

Ketahanan pangan adalah kondisi terpenuhinya pangan bagi negara sampai dengan perseorangan, yang tercermin dari tersedianya pangan yang cukup, baik jumlah maupun mutunya, aman, beragam, bergizi, merata, serta terjangkau dan tidak bertentangan dengan agama, keyakinan, serta budaya masyarakat, untuk dapat hidup sehat, aktif, dan produktif secara berkelanjutan. Dalam ketahanan pangan, susu merupakan salah satu sumber protein hewani terpenting di Indonesia.

Kambing Peranakan Ettawah (PE) merupakan jenis kambing yang dapat dimanfaatkan baik daging maupun susunya. Susu yang dihasilkan mengandung globul lemak kecil, protein lunak, kandungan kalsium, fosfor, vitamin A, B, E kompleks yang tinggi dan 
proporsi asam lemak rantai pendek dalam jumlah yang relatif tinggi sehingga mudah dicerna (Ceballos et al. 2009).

Mastitis merupakan peradangan pada jaringan internal ambing dan penyakit yang sangat umum terjadi di kambing perah. Bakteri Staphylococcus dan Streptococcus adalah agen dominan yang menyebabkan kejadian tersebut (Zhao et al. 2015). Menurut Sugiri \& Anri (2009), kejadian mastitis subklinis pada sapi perah di Pulau Jawa kebanyakan disebabkan oleh Streptococcus agalactiae atau Staphylococcus aureus. Begitupun dengan kambing PE yang juga rentan terhadap kejadian mastitis. Faktor penting terjadinya mastitis yaitu kondisi sanitasi kandang yang buruk atau pemerahan yang tidak higienis. Frekuensi pemerahan dua kali sehari juga menjadi penyebab mastitis karena mengakibatkan otot sphincter puting susu mengendor, sehingga bakteri mudah masuk ambing dan terjadi mastitis (Marogna et al. 2012). Produksi susu kambing dapat turun hingga sekitar 10-25\% akibat dari mastitis. Secara ekonomi juga terjadi peningkatan biaya pengobatan, meningkatnya jumlah hewan yang harus dikeluarkan, dan susu ditolak di pasaran karena jumlah sel somatik (JSS) lebih tinggi dari normal dan mengandung patogen (Leitner et al. 2004).

Beberapa hal yang dapat dilakukan untuk mencegah terjadinya mastitis yaitu penerapan manajemen pemeliharaan yang baik, pemerahan yang higienis, dan penggunaan antibiotik. Pencegahan lain yang dapat dilakukan yaitu dengan vaksin yang berasal dari bakteri penyebab mastitis tersebut (Lindahl et al. 2005). Saat ini sedang dikembangkan vaksin iradiasi menggunakan sinar gamma untuk mencegah mastitis subklinis. Radiasi adalah pancaran dan perambatan energi melalui materi atau ruang dalam bentuk gelombang elektromagnetik atau partikel. Sedangkan iradiasi merupakan istilah yang digunakan untuk aplikasi radiasi (BATAN 2008).

Berbagai aspek mengenai pencegahan mastitis secara umum telah banyak diteliti seperti pemberian berbagai jenis herbal (Nurdin et al. 2011) ataupun menggunakan ekstrak daun kersen (Mahardika et al. 2014) tetapi belum ada cara pencegahan mastitis yang efektif diaplikasikan sehingga kasus mastitis subklinis tetap terjadi di Indonesia. Penelitian ini dilakukan dalam upaya penyelesaian masalah untuk pencegahan mastitis subklinis pada ruminansia. Kebaruan dari penelitian ini adalah aplikasi teknik nuklir untuk vaksin iradiasi S. agalactiae dalam pencegahan mastitis subklinis.

Penelitian ini bertujuan untuk mengetahui profil darah kambing PE sebelum dan setelah melahirkan dengan pemberian vaksin iradiasi Streptococcus agalactiae untuk pencegahan mastitis subklinis.

\section{MATERI DAN METODE}

Penelitian ini menggunakan enam ekor kambing PE bunting yang diberi pakan yang sama dan dibagi menjadi dua kelompok perlakuan, yaitu tiga ekor untuk kelompok perlakuan (vaksin) dan tiga ekor untuk kelompok kontrol yaitu hewan sehat yang tidak diberi vaksin. Bahan dasar vaksin adalah bakteri S. agalactiae $10^{8} \mathrm{cfu} / \mathrm{ml}$ isolat lokal yang diradiasi dengan sinar gamma $17 \mathrm{~Gy}$. Vaksin yang digunakan sebanyak $2 \mathrm{ml} / \mathrm{ekor}$ secara subkutan di regio gumba (Tuasikal et al. 2012a). Pemberian vaksin dilakukan ketika kambing memasuki masa kering kandang setiap 2 minggu sekali dan pemberian dilakukan tiga kali sebelum kambing melahirkan. (Tuasikal et al. 2012b). Pembuatan vaksin iradiasi dilakukan dengan memberikan perlakuan radiasi pada bahan vaksin Streptococcus Grup B (SGB) di dalam gamma chamber irradiator yang terdapat di Balai Iradiasi, Elektronika dan Instrumentasi, Pusat Aplikasi Isotop dan Radiasi (PAIR), Badan Tenaga Nuklir Nasional (BATAN) Jakarta. 
Setiap kelompok dianalisis sebanyak empat kali, nilai yang tertulis merupakan nilai rata-rata kelompok. Nilai yang diperoleh kemudian dibandingkan dengan nilai normal yang diambil dari Jackson \& Cockcroft (2002). Pengamatan dilakukan terhadap gambaran darah, yaitu kadar hemoglobin, nilai hematokrit, penghitungan jumlah eritrosit dan leukosit. Selain itu juga diamati penambahan bobot badan harian kambing sebelum melahirkan dan setelah melahirkan. Pengambilan sampel darah dan penimbangan berat badan dilakukan dua minggu sekali mulai dari dua bulan sebelum kambing melahirkan hingga dua bulan setelah kambing melahirkan.

\section{HASIL DAN PEMBAHASAN}

Berdasarkan hasil pengamatan, diketahui hasil gambaran darah kambing kontrol dan kambing perlakuan sebelum melahirkan seperti terlihat pada Tabel 1 berikut.

Tabel 1. Hasil gambaran darah kambing PE perlakuan vaksinasi iradiasi S. agalactiae dan kambing PE kontrol sebelum melahirkan

\begin{tabular}{lccc}
\hline \hline Parameter & Kontrol & Perlakuan & Nilai normal \\
\hline Eritrosit $\left(\times 10^{6} \mathrm{sel} / \mu \mathrm{l}\right)$ & 10,9 & 10,6 & $8,0-18,0$ \\
Leukosit $\left(\times 10^{3} \mathrm{sel} / \mu \mathrm{l}\right)$ & 7,9 & 8,0 & $4,0-13,0$ \\
Hemoglobin $(\mathrm{g} / \mathrm{dl})$ & 10,2 & 10,1 & $8,0-12,0$ \\
PCV $(\%)$ & 32,4 & 29,8 & $22,0-38,0$ \\
\hline
\end{tabular}

Jumlah eritrosit, hemoglobin, dan nilai PCV sebelum melahirkan pada kambing kontrol tidak menunjukkan banyak perbedaan dibandingkan dengan kelompok kambing perlakuan. Akan tetapi pada nilai leukosit dapat diamati bahwa pada kambing perlakuan terlihat sedikit lebih tinggi dibandingkan dengan kelompok kontrol. Hal ini terjadi dikarenakan dilakukannya booster vaksin sehingga terbentuk imun sekunder terhadap antigen (Radji 2010). Limfosit yang terdapat pada leukosit kambing perlakuan dimobilisasi ke jaringan limfoid untuk pembentukkan antibodi akibat dari pemberian vaksin. Proses ini dapat berlangsung selama 3-14 hari. Selain itu neutrofil juga dimobilisasi ke jaringan tempat di mana vaksin disuntikkan (Lawhead \& James 2007).

Hasil dari penimbangan bobot badan, diketahui bahwa dinamika bobot hidup kambing PE baik itu kelompok kontrol maupun kelompok perlakuan selama periode kebuntingan disajikan pada Gambar 1. Selama periode tersebut semua kambing mengalami peningkatan bobot hidup. Hal ini disebabkan adanya pertumbuhan fetus dan perkembangan kelenjar ambing yang sangat pesat (Wahab \& Anderson 1989).

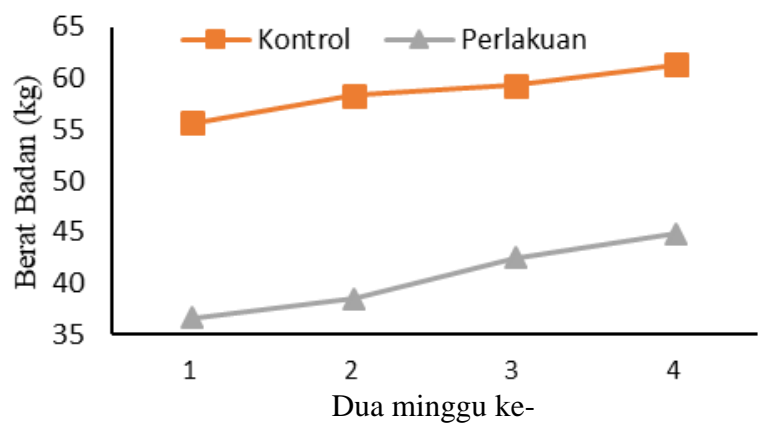

Gambar 1. Pertambahan bobot hidup kambing PE perlakuan vaksinasi iradiasi S. agalactiae dan kambing PE kontrol sebelum melahirkan 
Peningkatan produksi ditandai dengan adanya peningkatan bobot hidup kambing yang dipelihara secara semi intensif. Hasil penimbangan ternak setiap dua minggu menunjukkan bahwa kambing kelompok perlakuan memiliki rataan penambahan bobot badan harian sebelum melahirkan 194,4 g/ekor, sedangkan untuk kelompok kontrol memiliki penambahan bobot badan harian sebelum melahirkan 134,9 g/ekor. Penambahan bobot badan harian tersebut tergolong lebih tinggi dibandingkan yang pernah dilakukan oleh Novita et al. (2006) dimana penelitian tersebut dilakukan pada 24 ekor kambing PE dan memperoleh hasil pertambahan bobot badan harian kambing PE bunting berkisar antara 100-110 g/ekor. Setelah hewan melahirkan, gambaran darah kembali diamati dan tersaji seperti pada Tabel 2 berikut.

Tabel 2. Hasil gambaran darah kambing PE perlakuan vaksinasi iradiasi S. agalactiae dan kambing PE kontrol setelah melahirkan

\begin{tabular}{lccc}
\hline \hline Parameter & Kontrol & Perlakuan & Nilai normal \\
\hline Eritrosit $\left(\times 10^{6} \mathrm{sel} / \mu \mathrm{l}\right)$ & 12,3 & 10,9 & $8,0-18,0$ \\
Leukosit $\left(\times 10^{3} \mathrm{sel} / \mu \mathrm{l}\right)$ & 8,6 & 9,0 & $4,0-13,0$ \\
Haemoglobin $(\mathrm{g} / \mathrm{dl})$ & 9,8 & 10,0 & $8,0-12,0$ \\
PCV $(\%)$ & 33,2 & 33,1 & $22,0-38,0$ \\
\hline
\end{tabular}

Secara umum, jumlah eritrosit, haemoglobin, dan nilai PCV antara kelompok kontrol dan kelompok perlakuan masih tetap dalam nilai normal. Hal ini menunjukkan bahwa pemberian vaksin iradiasi tidak menyebabkan hewan menjadi anemia/kekurangan eritrosit dan haemoglobin. Sementara untuk nilai leukosit dapat diamati bahwa terjadi peningkatan dibandingkan sebelum hewan melahirkan. Hal ini wajar terjadi akibat dari stres yang dialami hewan ketika proses melahirkan. Stres mengakibatkan meningkatnya kadar kortisol sehingga jumlah neutrofil meningkat yang menyebabkan jumlah leukosit meningkat pula. Keadaan ini disebut sebagai leukositosis kortikosteroid (Stockham \& Scott 2008).

Setelah beranak, induk kambing otomatis mengalami penurunan bobot hidup dan memasuki periode laktasi. Penurunan ini terjadi karena kelahiran anak dan meningkatnya produksi susu. Hal ini seperti yang terlihat pada Gambar 2.

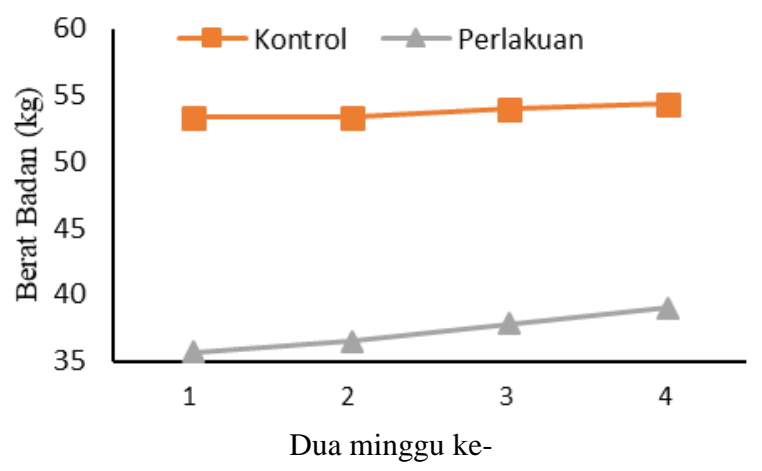

Gambar 2. Pertambahan bobot hidup kambing PE perlakuan vaksinasi iradiasi S. agalactiae dan kambing PE kontrol setelah melahirkan

Berdasarkan Gambar 2 dapat diketahui bahwa kambing kelompok perlakuan memiliki rataan penambahan bobot badan harian setelah melahirkan 79,4 g/ekor, sedangkan untuk kelompok kontrol memiliki penambahan bobot badan harian setelah melahirkan 23,8 g/ekor. Ali (2006) melaporkan bahwa pertambahan bobot badan harian pada 12 ekor 
kambing PE berkisar 71,9 g/ekor. Perbedaan pertambahan bobot badan harian ini dapat disebabkan karena kualitas dan kuantitas pakan yang diberikan berbeda. Cadangan zat makanan tubuh dimobilisasi untuk menyediakan nutrien sebagai bahan baku susu akibat pasokan zat makanan yang ada tidak mampu menyediakan nutrien sebagai bahan baku susu. Hal inilah yang menyebabkan turunnya bobot tubuh kambing. Mobilisasi juga disebabkan oleh kecepatan peningkatan konsumsi awal laktasi yang lebih lambat daripada kecepatan peningkatan produksi susu sehingga terjadi penyusutan bobot hidup (Sutardi 1981).

\section{KESIMPULAN}

Pemberian vaksin iradiasi $S$. agalactiae tidak menyebabkan anemia pada kambing PE baik selama kebuntingan maupun setelah melahirkan. Hal ini dapat dilihat dari nilai eritrosit, haemoglobin dan nilai PCV masih tetap dalam nilai normal. Vaksin ini juga dapat dikatakan efektif untuk membentuk sistem imun sekunder yang diamati melalui pengamatan jumlah leukosit. Sementara itu, dapat pula diketahui bahwa dengan pemberian vaksin iradiasi $S$. agalactiae tidak mempengaruhi penambahan bobot badan harian kambing PE selama kebuntingan maupun setelah melahirkan.

\section{UCAPAN TERIMA KASIH}

Penulis mengucapkan terima kasih kepada FKH IPB atas kerjasamanya selama ini. Ucapan yang sama disampaikan pula kepada seluruh staf peneliti dan teknisi di Laboratorium Kesehatan dan Reproduksi Ternak PAIR BATAN atas dukungannya pada penelitian ini.

\section{DAFTAR PUSTAKA}

Ali U. 2006. Pengaruh penggunaan onggok dan isi rumen sapi dalam pakan komplit terhadap penampilan kambing peranakan Ettawah. Maj Ilmu Peternak. 9:1-10.

BATAN. 2008. Dasar-dasar fisika radiasi. Jakarta (Indonesia): Pusat Pendidikan dan Pelatihan Badan Tenaga Nuklir Nasional.

Ceballos LS, Morales ER, Adarve G de la T, Castro JD, Martı'nez LP rez, Sampelayo MRS. 2009. Composition of goat and cow milk produced under similar conditions and analyzed by identical methodology. J Food Compos Anal. 22:322-329.

Jackson PGG, Cockcroft PD. 2002. Clinical examination of farm animals. Oxford (UK): Blackwell Publishing Company.

Lawhead B, James M. 2007. Introduction to veterinary science. New York (USA): Thomson Delmar Learning.

Leitner G, Merin U, Silanikove N. 2004. Changes in milk composition as affected by subclinical mastitis in goats. J Dairy Sci. 87:1719-1726.

Lindahl G, Stalhammar C, Areschoug T. 2005. Surface protein of Streptococcus agalactiae and related protein in other bacterial pathogen. Clin Microbiol Rev. [Internet]. [cited 2017 July 5]. Available from: https://www.ncbi.nlm.nih.gov/pmc/articles/PMC544178/.

Mahardika HA, Sarwiyono, Surjowardojo P. 2014. Ekstrak metanol daun kersen (Muntingia calabura L) sebagai antimikroba alami terhadap bakteri Staphylococcus aureus penyebab mastitis subklinis pada sapi perah. J Ternak Trop. 15:15-22. 
Marogna G, Pilo C, Vidili A, Tola S, Schianchi G, Leori SG. 2012. Comparison of clinical findings, microbiological results, and farming parameters in goat herds affected by recurrent infectious mastitis. Small Rumin Res. 102:74-83.

Novita CI, Sudono A, Sutama IK, Toharmat T. 2006. Produktivitas kambing Peranakan Ettawah yang diberi ransum berbasis jerami padi fermentasi. Media Peternak. 29:96-106.

Nurdin E, Amelia T, Makin M. 2011. The effects of herbs on milk yield and milk quality of mastitis dairy cow. J Indones Trop Anim Agric. 36:104-108.

Radji M. 2010. Imunologi dan virologi. 1st ed. Jakarta (Indonesia): PT ISFI.

Stockham SL, Scott MA. 2008. Fundamentals of veterinary clinical pathology. 2nd ed. Iowa (USA): Blackwell Publishing Company.

Sugiri YD, Anri A. 2009. Prevalensi patogen penyebab mastitis subklinis (Staphylococcus aureus dan Streptococcus agalactiae) dan patogen penyebab mastitis subklinis lainnya pada peternak skala kecil dan menengah di beberapa sentra peternakan sapi perah di Pulau Jawa. Prosiding Rapat Teknis dan Pertemuan Ilmiah Kesehatan Hewan Bogor. 1-7.

Sutardi T. 1981. Sapi perah dan pemberian makanannya. Bogor (Indonesia): Institut Pertanian Bogor.

Tuasikal B, Wibawan I, Pasaribu F, Estuningsih S. 2012a. Bacterial protein characterization of Streptococcus agalactiae by SDS-page method for subclinical mastitis irradiated vaccine materials in dairy cattle. Atom Indones. 38:66-70.

Tuasikal BJ, Pasaribu FH, Wibawan IWT. 2012b. Orientasi dosis iradiasi Streptococcus agalactiae untuk bahan vaksin mastitis subklinis pada sapi perah. A Sci J Appl Isot Radiat. 8:83-88.

Wahab IM, Anderson RR. 1989. Physiologic role of relaxin on mammary gland growth in rats. J Mo Agric Exp Stn. 192:285-289.

Zhao Y, Liu H, Zhao X, Gao Y, Zhang M, Chen D. 2015. Prevalence and pathogens of subclinical mastitis in dairy goats in China. Trop Anim Health Prod. 47:429-435. 